\title{
No high-risk HPV detected in SCC of the oral tongue in the absolute absence of tobacco and alcohol-a case study of seven patients
}

\author{
T. J. H. Siebers • M. A. W. Merkx • P. J. Slootweg • \\ W. J. G. Melchers • P. van Cleef • P. C. M. de Wilde
}

Published online: 2 September 2008

(C) The Author(s) 2008. This article is published with open access at Springerlink.com

\begin{abstract}
Introduction In recent years, there has been an increase in the number of patients with squamous cell carcinoma (SCC) of the mobile tongue in the absence of tobacco and alcohol. The literature suggests that human papilloma virus (HPV) may be involved in the development of SCC of the head and neck, especially in non-smoking and non-drinking patients. In the oral cavity, however, the presence of the HPV genome has been reported with various percentages. This may be due to misclassification of the oropharyngeal tongue as oral cavity subsite and the use of various detection methods.

Materials and methods Therefore, we evaluated the role of $\mathrm{HPV}$ in seven consecutive non-smoking and non-drinking patients (2003-2006) with a SCC located at the oral, mobile tongue using in situ hybridization and $\mathrm{SPF}_{10}$ Line Blot 25 polymerase chain reaction assays.

Results No HPV was detected in these specimens. To further determine whether a relationship exists between HPV and SCC in the absence of tobacco and alcohol, subsequent studies at specific locations are necessary.
\end{abstract}

T. J. H. Siebers $\cdot$ M. A. W. Merkx $(\square)$

Departments of Oral and Maxillofacial Surgery,

Radboud University Nijmegen Medical Centre,

Nijmegen, The Netherlands

e-mail:m.merkx@mka.umcn.nl

P. J. Slootweg • P. van Cleef $\cdot$ P. C. M. de Wilde

Departments of Pathology, Radboud University Nijmegen

Medical Centre,

Nijmegen, The Netherlands

W. J. G. Melchers

Departments of Medical Microbiology, Radboud University

Nijmegen Medical Centre,

Nijmegen, The Netherlands
Keywords Human papilloma virus · Oral cancer

\section{Introduction}

Oral cavity cancer is the eighth most common malignancy worldwide, with more than 300,000 new cases annually [1]. Although it is generally agreed that long-term tobacco, alcohol and betel quid consumption are the major environmental risk factors for the development of oral squamous cell carcinoma (SCC) $[1,2]$, in recent years, the Netherlands have seen an increase in the number of patients with an SCC of the mobile tongue in the absence of tobacco and alcohol. This rise is in line with studies suggesting that the incidence of tongue and tonsillar cancer is increasing in patients who have had no exposure to these traditional risk factors or with an exposure time not long enough for malignant transformation [2-4].

Nowadays, the question arises whether there is a possible association between this increased incidence of SCC of the tongue and tonsil and high-risk human papilloma virus (HRHPV) infection. It is generally accepted that there is a strong association between tonsillar SCC and HR-HPV [5-8]. However, with regard to the oral cavity, no unambiguous conclusions can yet be drawn as to whether HR-HPV also plays a role in the development of oral SCC $[2,5,9]$. The International Agency for Research on Cancer multicentre study by Herrero et al. [10] detected HR-HPV DNA in $3.9 \%$ of the biopsy specimens of the oral cavity, whereas a large population-based review study conducted by Kreimer et al. [11] reported that the HR-HPV prevalence in SCC of the oral cavity was $23.5 \%$.

The literature suggests that the variety of results can be attributed to geographical differences [2], different detection methods and their sensitivity $[2,12]$, but also to a 
misclassification of the oropharyngeal tongue, which is considered part of Waldeyer's tonsillar ring, as oral cavity subsite $[2,7,10]$. It has been suggested that this ring might be particularly susceptible to HPV, and therefore, cancer site misclassification is considered to be a serious problem that may bias risk estimates in many epidemiological studies [2].

To evaluate the oncogenetic role of HR-HPV in an absolute non-smoking and non-drinking patient group with an oral SCC of the mobile tongue, a case study was performed using two different detection methods.

\section{Materials and methods}

Clinical data concerning consecutive Dutch patients with histologically confirmed primary SCC of the mobile tongue, treated between 2003 and 2006, were obtained from the medical charts of the Department of Oral and Maxillofacial Surgery, Radboud University Nijmegen Medical Centre (RUNMC), The Netherlands. Patients who had been exposed to radiotherapy and chemotherapy in their history because of another oncological problem were excluded. Only patients who have never smoked and consumed alcoholic beverages up to one unit a day were included. These patients were screened for tobacco and alcohol use in their history, with a detailed retrospective review of the charts of the hospitals, of general dental practitioners and of general practitioners. This was confirmed by direct communication with the patient or close family. In addition, other data concerning sex, age at diagnosis, tumor histology, and tumor-node-metastases classification (according to the International Union Against Cancer) were obtained from their medical charts.

Consequently, the paraffin-embedded tissue resections from seven consecutive patients were retrieved from the archives of the Department of Pathology, RUNMC. For each patient, a total of three stained microscopic sections were evaluated; one section was stained with haematoxylin and eosin, two stained for the detection of HPV. It was determined which sections of each tumour were most suitable for inclusion in our study, based on the presence of sufficient numbers of tumour cells, the absence of damaged malignant tissue and, where possible, the presence of normal and/or dysplastic epithelium for comparison purposes. These obtained specimens were tested by in situ hybridization (ISH) [13] (HPV 16/18 and 31/33) and a short polymerase chain reaction (PCR) Fragment-PCR $\left(\mathrm{SPF}_{10}\right.$ Line Blot 25 PCR) [14] assay. This PCR assay amplifies a fragment of only $65 \mathrm{bp}$ and is therefore considered a highly sensitive detection method for different HPV types (up to 43 individual HPV-types) on paraffin-embedded specimens in particular $[14,15]$. Consequently, this combined detectiongenotyping assay is used in the routine clinical practice of screening cervical scrapes and oral and cervical research applications $[14,16]$. The integrity of the extracted DNA was also determined by amplification of the $\beta$-globin gene, which also served as an internal amplification check.

To avoid cross-contamination with HPV, all tissue specimens were processed separately. A tissue block from a confirmed HR-HPV-positive tonsil carcinoma was used as a positive control. Both assays were performed as previously described $[13,14]$.

\section{Results}

No HR-HPV was detected in the primary tumours of the seven consecutive non-smoking and non-drinking Dutch patients using ISH and $\mathrm{SPF}_{10}$ Line Blot 25 PCR assays (Table 1).

\section{Discussion}

We evaluated the oncogenetic role of HR-HPV in an absolute non-smoking and non-drinking patient group with an oral SCC of the mobile tongue using two different detection methods. According to the literature, there are two specific European studies that differentiate between SCC of the oral tongue and carcinomas originating from the base of the tongue [17, 19]. Kantola et al. [17] could not detect HRHPV in 105 specimens of the oral tongue, whereas Dahlgren et al. [19] found only two of the 85 analysed mobile tongue cancers to be HR-HPV positive. However, it remains unclear if these studies included absolute non-smoking and nondrinking patients.

Table 1 Patient data

Follow-up interval: months 1 Yes, 0 no

\begin{tabular}{lllccc}
\hline Age & Sex & Pathology stage & Recurrence & Survival & Follow-up interval \\
\hline 23 & Female & $\mathrm{pT}_{1} \mathrm{~N}_{0} \mathrm{M}_{0}$ & 1 & 0 & 10 \\
49 & Male & $\mathrm{pT}_{1} \mathrm{~N}_{0} \mathrm{M}_{0}$ & 0 & 1 & 40 \\
95 & Female & $\mathrm{pT}_{3} \mathrm{~N}_{0} \mathrm{M}_{0}$ & 0 & 1 & 38 \\
44 & Male & $\mathrm{pT}_{3} \mathrm{~N}_{1} \mathrm{M}_{0}$ & 0 & 1 & 24 \\
37 & Male & $\mathrm{pT}_{1} \mathrm{~N}_{0} \mathrm{M}_{0}$ & 0 & 1 & 37 \\
56 & Female & $\mathrm{pT}_{1} \mathrm{~N}_{0} \mathrm{M}_{0}$ & 1 & 1 & 26 \\
40 & Female & $\mathrm{pT}_{2} \mathrm{~N}_{0} \mathrm{M}_{0}$ & 0 & 1 & 57 \\
\hline
\end{tabular}


Based on the literature, infection with HR-HPV has been suggested as a risk factor for the development of SCC of the head and neck (HNSCC) in non-smoking patients [2, $10,12]$. Yet almost all studies known in the absence of tobacco and alcohol were conducted in HNSCC in general $[18,21]$. In a study by Dahlstrom et al. [18], 60 nonsmoking patients with a developed HNSCC were evaluated for the presence of HR-HPV. Nevertheless, 17 of these patients appeared to have an SCC of the oral tongue, and only one appeared to be HR-HPV positive. These results seem to be in line with the results of our study. However, the results of the study by Dahlstrom et al. [18] were based on serological antibody testing which is not considered a standard method because of the low sensitivity and specificity of the assays [20].

According to the literature, the various reported HPV percentages in the oral cavity may be due to the different sampling and detection methods used [2, 12]. For instance, according to McKaig et al. [22], the HPV prevalence in HNSCC as detected by PCR was $34.5 \%$, by ISH $15.8 \%$, and by Southern blot 24.5\%. According to Gillison [23], ISH assays may have limited sensitivity for some HPV types, and therefore, the validity of the prevalence data is unproven. It has been suggested that conventional PCRbased assays can be hampered in archival smears or paraffinembedded materials [15, 24]. Therefore, we used SPF PCR primers that permit $100 \%$ detection of HPV DNA in paraffin-embedded materials [15, 25].

Based on the results found in our case study and the results found by Dahlstrom et al. [18], Kantola et al. [17] and Dahlgren et al. [19], it seems that HR-HPV is not involved in the development of SCC of the oral tongue. However, to further determine whether a relationship exists between HR-HPV and OSCC in the absence of tobacco and alcohol, further research is necessary. To ease comparability between different studies, it seems recommendable to take into account the type of detection assays and misclassification of anatomical tumour sites.

Open Access This article is distributed under the terms of the Creative Commons Attribution Noncommercial License which permits any noncommercial use, distribution, and reproduction in any medium, provided the original author(s) and source are credited.

\section{References}

1. Tsantoulis PK, Kastrinakis NG, Tourvas AD, Laskaris G, Gorgoulis VG (2007) Advances in the biology of oral cancer. Oral Oncol 43:523-534

2. Li G, Sturgis EM (2006) The role of human papillomavirus in squamous carcinoma of the head and neck. Curr Oncol Rep 8:130-139

3. Lam L, Logan RM, Luke C, Rees GL (2007) Retrospective study of survival and treatment pattern in a cohort of patients with oral and oropharyngeal tongue cancers from 1987 to 2004. Oral Oncol 43:150-158

4. Golas SM (2007) Trends in palatine tonsillar cancer incidence and mortality rates in the United States. Community Dent Oral Epidemiol 35:98-108

5. Shiboski CH, Schmidt BL, Jordan RC (2005) Tongue and tonsil carcinoma: increasing trends in the U.S. population ages 20 44 years. Cancer 103:1843-1849

6. Klussmann JP, Weissenborn SJ, Wieland U, Dries V, Eckel HE, Pfister HJ, Fuchs PG (2003) Human papillomavirus-positive tonsillar carcinomas: a different tumor entity? Med Microbiol Immunol 192:129-132

7. Paz IB, Cook N, Odom-Maryon T, Xie Y, Wilczynski SP (1997) Human papillomavirus (HPV) in head and neck cancer. An association of HPV 16 with squamous cell carcinoma of Waldeyer's tonsillar ring. Cancer 79:595-604

8. Mork J, Lie AK, Glattre E, Hallmans G, Jellum E, Koskela P, Moller B, Pukkala E, Schiller JT, Youngman L, Lehtinen M, Dillner J (2001) Human papillomavirus infection as a risk factor for squamous-cell carcinoma of the head and neck. N Engl J Med 344:1125-1131

9. Sugarman PB, Shillitoe EJ (1997) The high risk human papillomaviruses and oral cancer: evidence for and against a causal relationship. Oral Dis 3:130-147

10. Herrero R, Castellsague X, Pawlita M, Lissowska J, Kee F, Balaram P, Rajkumar T, Sridhar H, Rose B, Pintos J, Fernandez L, Idris A, Sanchez MJ, Nieto A, Talamini R, Tavani A, Bosch FX, Reidel U, Snijders PJ, Meijer CJ, Viscidi R, Munoz N, Franceschi S, IARC Multicenter Oral Cancer Study Group (2003) Human papillomavirus and oral cancer: the International Agency for Research on Cancer multicenter study. J Natl Cancer Inst 95:17721783

11. Kreimer AR, Clifford GM, Boyle P, Franceschi S (2005) Human papillomavirus types in head andneck squamous cell carcinomas worldwide: a systematic review. Cancer Epidemiol Biomarkers Prev 14:467-475

12. Gillison ML, Koch WM, Capone RB, Spafford M, Westra WH, Wu L, Zahurak ML, Daniel RW, Viglione M, Symer DE, Shah KV, Sidransky D (2000) Evidence for a causal association between human papillomavirus and a subset of head and neck cancers. J Natl Cancer Inst 92:709-720

13. Poddighe PJ, Bulten J, Kerstens HM, Robben JC, Melchers WJ, Hanselaar AG (1996) Human papilloma virus detection by in situ hybridisation signal amplification based on biotinylated tyramine deposition. Clin Mol Pathol 49:340-344

14. Melchers WJG, Bakkers JMJE, Wang J, De Wilde PCM, Boonstra H, Quint WGV, Hanselaar AGJM (1999) Short fragment polymerase chain reaction reverse hybridization line probe assay to detect and genotype a broad spectrum of human papillomavirus types. Am J Pathol 155:1473-1478

15. Kleter B, van Doorn LJ, Schrauwen L, Molijn A, Sastrowijoto S, ter Schegget J, Lindeman J, ter Harmsel B, Burger M, Quint W (1999) Development and clinical evaluation of a highly sensitive PCR-reverse hybridization line probe assay for detection and identification of anogenital human papillomavirus. J Clin Microbiol 37:2508-2517

16. El-Mofty SK, Patil S (2006) Human papillomavirus (HPV)-related oropharyngeal nonkeratinizing squamous cell carcinoma: characterization of a distinct phenotype. Oral Surg Oral Med Oral Pathol Oral Radiol Endod 101:339-345

17. Kantola S, Parikka M, Jokinen K, Hyrynkangs K, Soini Y, Alho OP, Salo T (2000) Prognostic factors in tongue cancerrelative importance of demographic, clinical and histopathological factors. Br J Cancer 83:614-619

18. Dahlstrom KR, Adler-Storthz K, Etzel CJ, Liu Z, Dillon L, El-Naggar AK, Spitz MR, Schiller JT, Wei Q, Sturgis EM (2003) Human papillomavirus type 16 infection and squamous cell 
carcinoma of the head and neck in never-smokers: a matched pair analysis. Clin Cancer Res 9:2620-2626

19. Dahlgren L, Dahlstrand HM, Lindquist D, Hogmo A, Bjornestal L, Lindholm J, Lundberg B, Dalianis T, Munck-Wikland E (2004) Human papillomavirus is more common in base of tongue than in mobile tongue cancer and is a favorable prognostic factor in base of tongue cancer patients. Int $\mathrm{J}$ Cancer 112:1015-1019

20. Pagliusi SR, Garland SM (2007) International standard reagents for HPV detection. Dis Markers 23:283-296

21. Fouret P, Monceaux G, Temam S, Lacourreye L, St Guily JL (1997) Human papillomavirus in head and neck squamous cell carcinomas in nonsmokers. Arch Otolaryngol Head Neck Surg 123:513-516
22. McKaig RG, Baric RS, Olshan AF (1998) Human papillomavirus and head and neck cancer: epidemiology and molecular biology. Head Neck 20:250-265

23. Gillison KL (2006) Human papillomavirus and prognosis of oropharyngeal squamous cell carcinoma: implications for clinical research in head and neck cancers. J Clin Oncol 24:5623-5625

24. da Silva CE, da Silva ID, Cerri A, Weckx LL (2007) Prevalence of human papillomavirus in squamous cell carcinoma of the tongue. Oral Surg Oral Med Oral Pathol Oral Radiol Endod 104:497-500

25. Kleter B, van Doorn LJ, ter Schegget J, Schrauwen L, van Krimpen K, Burger M, ter Harmsel B, Quint W (1998) Novel short-fragment PCR assay for highly sensitive broad-spectrum detection of anogenital human papillomaviruses. Am J Pathol 153:1731-1739 